\title{
Study of angiotensin converting enzyme and genotype among Egyptian preeclampsia patients
}

\author{
Hassan A. Alsokary ${ }^{1}$, Mostafa A. Kamel ${ }^{1}$, Sameh S. Sadek ${ }^{1}$, Nermine H. Zakaria ${ }^{2}$, \\ Iman A. Abdel Fatah ${ }^{1}$ \\ ${ }^{1}$ Obstetrics and Gynecology Department, Faculty of Medicine, Alexandria University, Alexandria, Egypt \\ ${ }^{2}$ Clinical Pathology Department, Faculty of Medicine, Alexandria University, Alexandria, Egypt \\ Email: nermohz@gmail.com
}

Received 10 December 2013; revised 30 December 2013; accepted 10 January 2014

Copyright (C) 2014 Hassan A. Alsokary et al. This is an open access article distributed under the Creative Commons Attribution License, which permits unrestricted use, distribution, and reproduction in any medium, provided the original work is properly cited. In accordance of the Creative Commons Attribution License all Copyrights (c) 2014 are reserved for SCIRP and the owner of the intellectual property Hassan A. Alsokary et al. All Copyright (C) 2014 are guarded by law and by SCIRP as a guardian.

\section{ABSTRACT}

Preeclampsia is a frequent disorder with reported incidence in pregnancies. In Egypt, it complicates 6\% $8 \%$ of pregnancies and reaches $15 \%$ in referral centers. The renin-angiotensin system activation during the early stages of Preeclampsia proved to be a direct cause. Women carrying the $D$ allele of the $A C E-I / D$ polymorphism have higher measures of uterine artery resistance, which is a marker for development of intrauterine growth retardation and preeclampsia. The maternal syndrome of preeclampsia (PE) during the latter half of pregnancy is believed to result from impaired placentation in early gestation and a failure to develop low resistance uteroplacental circulation. Aim: The aim of this study was to evaluate the association with angiotensin converting enzyme gene polymorphism and changes in its enzyme serum level in preeclamptic patients compared to non preeclamptic control group together with studying the changes in umbilical artery and uterine artery Doppler. Subjects: The study was conducted on 180 pregnant women allocated into two groups having the same inclusion and exclusion criteria except for hypertension and proteinuria; each group comprised of 90 pregnant women with matched age. Methods: Doppler study of umbilical and uterine arteries and the detection of Angiotensin converting gene polymorphism by PCR with Estimation of serum ACE in serum by ELISA technique. Results: The distribution of the ACE-I/D genotypes and allelic frequencies in the present study of polymorphism was $37.8 \%$ for the DD, $\mathbf{4 8 . 9 \%}$ for the ID, $13.3 \%$ for the II in preeclampsia group while it was $33.3 \%$ for the DD, $46.7 \%$ for the ID, and $20 \%$ for the II in the control group. There was no signifi- cant difference between cases and controls regarding the cumulative $D$ effect. Conclusions: No existence of a relation between preeclampsia and ACE gene polymorphism considering different modes of inheritance whether is dominance or recessiveness. No effect of ACE gene polymorphism is on ACE serum level. Positive correlation between ACE gene polymorphism and the uterine artery Doppler changes gives strong evidence that ACE gene may have a role in the histopathological changes taking place in these vessels, therefore affecting maternal prognosis. It is unclear to explain this mismatched ACE genetic influence on the incidence of preeclampsia, but the multifactorial pathogenesis of the development and complication in preeclampsia and also physician's intervention may contribute to the pregnancy outcome. Recommendations: International collaborations, particularly among countries with a high incidence of preeclampsia, may help to include participants with different cultural and genetic backgrounds, which can provide further insight into the etiology of the disease both genetic and environmental.

\section{KEYWORDS}

ACE: Angiotensin Converting Enzyme; Preeclampsia; Polymorphism; Doppler

\section{INTRODUCTION}

Preeclampsia is a frequent disorder with reported incidence in pregnancies. However, geographic, social, economic and racial differences are thought to be responsible for higher incidence rate in some populations $[1,2]$. 
In Egypt, the disease complicates 6\% - 8\% of all pregnancies and can reach up to $15 \%$ [3]. While maternal mortality due to preeclampsia is $10.01 \%$ - $20 \%$, preeclampsia/eclampsia probably accounts for more than 50,000 maternal deaths worldwide each year $[2,4]$.

Angiotensin I converting enzyme (ACE) is a monomeric, membrane-bound, zinc and chloride dependent peptidyl dipeptidase that catalyzes the conversion of the decapeptide angiotensin I to the octapeptide angiotensin II, by removing a carboxyterminal dipeptide. ACE has long been known to be a key part of the renin angiotensin system that regulates blood pressure [5].

There are two forms of the enzyme in humans, the somatic ACE and the sperm-specific germinal ACE, both encoded by the same gene through transcription from alternative promoters.

The rennin angiotensin system may be activated during the early stages of Preeclampsia and subsequently suppressed. In some populations, a relatively common polymorphism is present in raised frequency in women with $\mathrm{PE}$, but it is also raised in non pregnant hypertensive subjects. Furthermore, its expression is significantly raised in the decidual spiral arteries; abnormal placentation is a feature of PE [6].

Angiotensin II levels are modulated by ACE, whose plasma levels have been associated with the insertion/ deletion (I/D) polymorphism in intron 16 of the ACE gene. The ACE I/D polymorphism accounted for $47 \%$ of total phenotypic variance of serum ACE, contributing to the variability of ACE level. Serum ACE is widely recognized as a marker of disease activity.

A marked difference in serum ACE levels was observed between subjects in each of the 3 genotype classes; DD genotype is associated with higher serum ACE levels, whereas the II genotype is associated with lower levels; the ID genotype is associated with intermediate levels [6]. Moreover, it has been assumed that the I allele has a sequence similar to a silencer sequence, which might explain why the $\mathrm{D}$ allele is associated with higher ACE levels than the I allele. Several studies have reported that women carrying the D allele of the ACE I/D polymorphism have higher measures of uterine artery resistance, which is a marker for development of intrauterine growth retardation and preeclampsia $[7,8]$.

These observations led to the proposal that the $A C E$ $I / D$ polymorphism may be a good candidate to be correlated with the serum level of ACE in the search for a cause of preeclampsia. A common insertion/deletion polymorphism within the angiotensin-I converting enzyme gene $(A C E-I / D)$ has been reliably associated with substantial differences in the plasma and tissue angiotensin converting enzyme (ACE) activity in a codominant (additive) fashion with an influence that varies in populations of different ethnic origins $[9,10]$.
Individuals carrying the $D$ allele have higher ACE activity, which has been proposed as an intermediate phenotype of potential relevance for the development of high blood pressure and subclinical atheroma (i.e., higher intima-media thickness of the carotid artery) [11]. Despite the biological plausibility and the consistency of the effect of the ACE $I / D$ polymorphism on ACE activity, associations of the ACE $I / D$ polymorphism and coronary heart disease, coronary artery restenosis, stroke, and renal disease have been inconsistent [12].

It is evident that Angiotensin I and II are substrates for ACE2 whose plasma levels have been associated with the insertion/deletion (I/D) polymorphism in intron 16 of the ACE gene and are present in raised frequency in women with PE, and moreover, Angiotensinogen gene expression is significantly raised in the decidual spiral arteries and therefore abnormal placentation is a feature of PE.

\section{AIM OF THE WORK}

The aim of this study was to evaluate the association of angiotensin converting enzyme gene polymorphism and changes in its enzyme serum level in preeclamptic patients compared to non preeclamptic control group together with studying the association of preeclampsia and the changes in umbilical artery and uterine artery Doppler.

\section{SUBJECTS AND METHODS}

The study was conducted on 180 pregnant women recruited from the Maternity Hospital Alexandria Faculty of Medicine; all individuals were allocated into two groups:

Preeclampsia group consisted of 90 cases and Controls group which include 90 normotensive pregnant women.

All subjects signed an informed written consent before enrollment in the study and the approval of Medical Ethics Committee of Alexandria Faculty of Medicine was obtained.

\subsection{Inclusion Criteria}

1) Proteinuria defined by 2 clean catch midstream or catheter specimen of urine collected at 4 hours or more apart $2+$ or more on dipstick or $1 \mathrm{gm} / \mathrm{L}$ or more albumin in 24 hrs collected urine sample.

2) Blood pressure measuring more than $140 / 90 \mathrm{mmHg}$.

3) Positive past history or family history of pre-eclampsia.

4) Maternal weight more than $85 \mathrm{~kg}$.

5) Gestational age more than or equal to 24 weeks.

\subsection{Exclusion Criteria Included}

1) Rh negative cases. 
2) Medical diseases that may lead to hypertension e.g. essential hypertension, renovascular hypertension, chronic renal disease, primary hyperaldosteronism, and pheochromocytoma.

\subsection{Control Group}

They are normotensive pregnant women without hypertension or proteinurea and having the same selection and exclusion criteria as those of cases with matched age.

\subsection{All Patients Were Subjected to the Following}

1) Full history taking: Age, gravidity, parity, date of the last menstrual period to estimate the gestational age and family history of preeclampsia.

2) Medical history: to exclude medical diseases e.g. essential hypertension, renovascular hypertension, chronic renal disease, primary hyperaldosteronism, pheochromocytoma, coarcotation of aorta.

3) General examination: which include Vital signs, Body weight?

4) Obstetric examination: Fundal height, lie, presentation.

5) Abdominal ultrasound examination:

a) Diagnostic ultrasonography to determine:

i) Gestational age.

ii) Number of fetuses.

iii) Amniotic fluid index (by the four quadrant technique). Assessment of the amniotic fluid volume was done using the amniotic fluid index (AFI): Using the maternal umbilicus as a reference point, the abdomen is divided into our quadrants. With the ultra-sound probe held in the longitudinal axis of the mother and perpendicular to the floor, the largest vertical pool depth in each quadrant is recorded. The sum of these measurements represents the amniotic fluid index. Although the (AFI) is known to vary with gestational age, an AFI $<5 \mathrm{~cm}$ is classified as oligohydraminos and an AFI $>25 \mathrm{~cm}$ is classified as polyhydraminos [13].

iv) Presence of IUGR by measuring biparietal diameter (BPD), femur length (FL), head circumference/abdominal circumference ratio (HC/AC), and defined as fetal weight less than the $10^{\text {th }}$ centile for gestation $[14,15]$.

\section{b) Doppler studies:}

i) Umbilical and uterine arteries indices:

All these values were automatically calculated by the built-in soft-ware programs in the machine.

ii) Systolic/ diastolic ratio $(S / D)$ :

It is the simplist and is expressed by $S / D$, where $S$ is the peak systolic frequency and the $D$ is the end diastolic frequency.

iii) Resistance index $(R I)$ :

Known as Pourcelot's ratio examines the difference between the peak systolic and the end diastolic velocity and is expressed by:

$$
R I=(S-D) / S
$$

where $S$ is the peak systolic velocity and $D$ is the minimum or end diastolic velocity.

iv) Pulsatility index $(P I)$ :

Known as the mean pulsatility index to distinguish it from the peak to peak pulsatility index, it is expressed by:

$$
P I=(S-D) / \text { velocity }_{m}
$$

where $S$ is the peak systolic velocity and $D$ is the end diastolic velocity and the velocity ${ }_{m}$ is the time averaged maximum velocity over the cardiac cycle, it's calculated from the average of three or four cardiac cycles [14].

v) Vaginal measurement of uterine artery Doppler indices

The uterine arteries were examined at the level of the internal os where the artery approaches the uterus laterally. The internal os was viewed first in the sagittal plane. The probe was then turned to the transverse position and angled upwards to the long axis of the uterus. The vascular bundles were then visible and pulsations could be seen in real time, helping to identify the uterine arteries. The characteristic blood-flow velocity waveforms were obtained by placing the Doppler gate over the identified vessel.

6) Laboratory investigations:

a) Estimation of serum ACE:

This assay uses the quantitative sandwich enzyme immunoassay technique with a kit derived from R \& D (USA) using a specific monoclonal antibody specific for ACE.

b) Determination of ACE genotypes:

i) The D and I alleles were identified by the use of polymerase-chain-reaction (PCR) amplification of the respective fragments from intron 16 of the ACE gene and size fractionation and visualization was done by agarose gel electrophoresis.

ii) Fresh blood was collected on EDTA tubes; genomic DNA was extracted using GFX extraction purification kit from Amersham, USA.

iii) The amplification (PCR) was done using Perkin Elmer Techne thermal cycler machine in a final volume of $50 \mu \mathrm{l}$ PCR reaction mixture which contains $5 \mu \mathrm{l} 10 \times$ PCR Buffer, $3 \mu$ l of $25 \mathrm{mM} \mathrm{MgCl}_{2} \times 2 \mathrm{U}$ of Taq polymerase in a final concentration of $1.5 \mathrm{~nm}$.

iv) Optimized primer pair to amplify the D and I alleles, resulting in 319-bp and 597-bp amplicons, respectively. The forward primer was hace3 (5'GCC CTG CAG GTG TCT GCA GCA TGT3'’) and the reverse primer (5'GGA TGG CTC TCC CCG CCT TGT CTC3'’). The master mix contained $4 \mu \mathrm{l}$, dNTP mix, 
$30.6 \mu \mathrm{l}$ Nuclease free water, $0.4 \mu \mathrm{l}$ Taq polymerase and 5 $\mu \mathrm{l}$ genomic DNA equivalent to $100 \mathrm{ng} / \mu \mathrm{l}$.

v) Reaction tubes were inserted and the following protocol was set:

Pre PCR $94^{\circ} \mathrm{C}$ for 5 min for denaturation of genomic DNA, denaturation at $94^{\circ} \mathrm{C}$ for 30 seconds, annealing at $56^{\circ} \mathrm{C}$ for 45 seconds, and extension at $72^{\circ} \mathrm{C}$ for 2 minutes, repeated for 35 cycles, followed by a final extension at $72^{\circ} \mathrm{C}$ for 7 minutes. The amplification product was analyzed on $3 \%$ agarose gel and visualized by staining with ethidium bromide revealing bands of 319 bp for the D alleles and 597 bp amplicons for the I alleles; in heterozygous samples a third band, assumed to represent a heteroduplex (heterozygous) DNA product, was commonly seen. Because the $\mathrm{D}$ allele in heterozygous samples is preferentially amplified each sample found to have the DD genotype was subjected to a second, independent nested PCR amplification with a primer pair that recognizes an insertion-specific sequence (hace5a5'TGG GAC CAC AGC GCC CGC CAC TAC3'; hace5c, 5'TCG CCA GCC CTC CCA TGC CCA TAA3'), with identical PCR conditions except for an annealing temperature of $67^{\circ} \mathrm{C}$. The reaction yields a 335-bp amplicon only in the presence of an I allele and no product in samples homozygous for DD. This procedure correctly identified the 4 to 5 percent of samples with the DI genotype that are misclassified as DD with the insertion-spanning primers as shown in Figure 1.

\section{STATISTICAL METHODOLOGY}

After data entry into a specially designed sheet using Microsoft Excel, a print out of the data was thoroughly revised and entry mistakes were corrected. Data were then transferred to SPSS ver. 17 format and the following statistics were performed:

1) Exploratory data analysis (EDA): to examine the distribution of variable whether they are normally distributed or not, and to test for outliers or extremes values.

2) Descriptive statistics: for quantitative data, minimum, maximum, mean and standard deviation were calculated, for qualitative data the median and range were calculated.

3) Comparative statistics were carried out between the

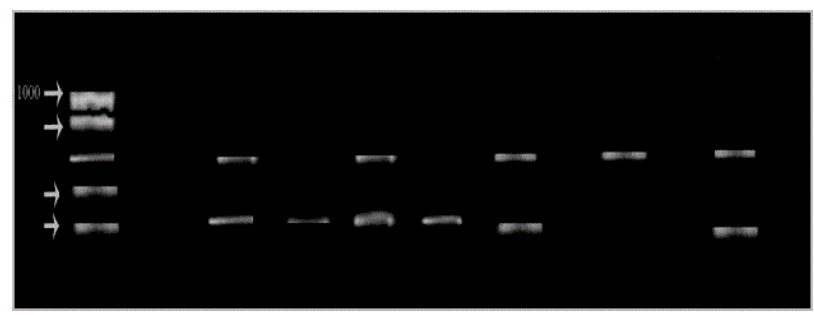

Figure 1. Typical PCR amplification electrophoretograms showing different ACE genotyoes. two groups in all variables studied using student independent t-test and One Way Analysis of Variance (ANOVA) test for quantitative normally distributed variables, for post-hoc test, Tukey HSD method was adopted when equal variance of the subgroups was assumed. Non-parametric statistics (Mann Whitney, Kruskal-Wallis test) were used for comparison of ranks, small scales or non-normally distributed variables.

4) Chi-square was used to test for association between the two studied groups and also between the patients' subgroups.

5) The frequencies of the alleles and genotypes among the cases and controls were counted and were compared by the Chi-square with the values predicted by the assumption of Hardy-Weinberg equilibrium in the sample.

A 5\% alpha error and $80 \%$ beta error were adopted in the study. $p$ significance was measured at $0.05 \%$.

\section{RESULTS}

\section{1) Demographic data shown in Table 1}

a) Age:

There was no statistically significant difference in age between the two groups ( $\mathrm{t}=0.602, p=0.549$ ). Comparing the three groups after dividing the cases into two groups mild PE and severe PE using ANOVA (F-ratio), there was no statistically significant difference in age ( $\mathrm{F}$ $=0.596, p=0.553)$. This assures that the age was matched among the studied subgroups and homogenously distributed.

b) Gravidity:

Using the Mann-Whitney U test, there was no statistically significant difference in gravidity between the two studied groups $(\mathrm{Z}=0.300, p=0.764)$.

Using the Kruskal-Wallis test there was no statistically significant difference in gravidity among the three studied subgroups $\left(\mathrm{X}^{2}=0.133, p=0.936\right)$. These results assure that the groups were matched as regards gravidity.

c) Parity:

Using the Mann-Whitney U test, there was no statistically significant difference in parity between the two studied groups $(\mathrm{Z}=0.774, p=0.439)$. Using the Krus-

Table 1. Demographic data among cases and controls.

\begin{tabular}{cccc}
\hline & $\begin{array}{c}\text { Preeclampsia } \\
\text { group (n=9) }\end{array}$ & $\begin{array}{c}\text { Control group } \\
(\mathbf{n}=\mathbf{9 0})\end{array}$ & Significance \\
\hline $\begin{array}{c}\text { Age (years) } \\
\text { Min - Max }\end{array}$ & $20-42$ & $21-40$ & $\mathrm{t}=0.602$ \\
Mean \pm S.D. & $28.87 \pm 5.57$ & $28.20 \pm 4.911$ & $p=0.549$ \\
Gravidity & & & \\
Min - Max & $1-8$ & $1-6$ & $\mathrm{Z}_{\mathrm{MW}}=0.300$ \\
Median & 3 & 3 & $p=0.764$ \\
Parity & & & \\
Min - Max & $0-5$ & $0-5$ & $\mathrm{Z}_{\mathrm{MW}}=0.774$ \\
Median & 1 & 1 & $p=0.439$ \\
\hline
\end{tabular}


kal-Wallis test there was no statistically significant difference in parity among the three studied subgroups $\left(\mathrm{X}^{2}\right.$ $=1.876, p=0.391)$. These results assure that the groups were matched as regards and parity.

2) Pulse rate, systolic, diastolic blood pressure, and respiratory rate

Pulse rate, systolic, diastolic blood pressure, and respiratory rate data as shown in Tables 2 and 3.

\section{a) Pulse:}

There was no statistically significant difference in the pulse rate between the two groups $(\mathrm{t}=1.724, p=0.088)$.

Using One-way independent analysis of variance (ANOVA) test, there was a statistically significant difference in the pulse rate among the three studied subgroups $(\mathrm{F}=4.377, p=0.015)$. Further analysis using Tukey HSD method for post-hoc revealed that there was only statistically significant difference between mild and control subgroups as mild preeclampsia patient had higher mean pulse rate when compared with the control group.

\section{b) Systolic blood pressure:}

Higher mean SBP was statistically significant when compared to control group ( $\mathrm{t}=19.341, p=0.000)$. Using One-way independent analysis of variance (ANOVA) test, there was (by definition) a statistically significant difference in the systolic blood pressure among the three studied subgroups $(F=269.732, p=0.000)$. Further analysis using Tukey HSD method for post-hoc revealed that higher level of SBP was found in severe, than in mild and in control patients.

c) Diastolic blood pressure:

Higher mean DBP statistically significant when compared to control group $(\mathrm{t}=13.177, p=0.000)$. Using One-way independent analysis of variance (ANOVA) test, there was a statistically significant difference in the diastolic blood pressure among the three studied subgroups $(\mathrm{F}=127.421, p=0.000)$. Further analysis using Tukey HSD method for post-hoc revealed that higher level of DBP was found in severe, than in mild and in control patients.

d) Respiratory rate:

There was no statistically significant difference in the respiratory rate between the two groups $(\mathrm{t}=0.569, p=$ $0.571)$.

Using One-way independent analysis of variance (ANOVA) test, there was no statistically significant difference in the respiratory rate among the three studied subgroups $(\mathrm{F}=2.054, p=0.134)$.

Table 2. Comparison for pulse rate, blood pressure, and respiratory rate.

\begin{tabular}{|c|c|c|c|}
\hline & Preeclampsia group $(n=90)$ & Control group $(n=90)$ & Significance \\
\hline \multicolumn{4}{|c|}{ Pulse rate (beats/min) } \\
\hline Min - Max & $70-90$ & $70-87$ & $\mathrm{t}=1.724$ \\
\hline \multicolumn{4}{|l|}{ SBP (mmHg) } \\
\hline Min - Max & $140-180$ & $90-140$ & $\mathrm{t}=19.341$ \\
\hline Mean \pm S.D. & $160.67 \pm 11.947$ & $114.67 \pm 10.574$ & $p=0.000^{*}$ \\
\hline \multicolumn{4}{|l|}{ DBP (mmHg) } \\
\hline Min - Max & $80-120$ & $60-90$ & $\mathrm{t}=13.177$ \\
\hline Mean \pm S.D. & $102.00 \pm 10.357$ & $76.22 \pm 8.059$ & $p=0.000^{*}$ \\
\hline \multicolumn{4}{|c|}{ Respiratory rate (breaths/min) } \\
\hline Min - Max & $12-17$ & $12-18$ & $t=0.569$ \\
\hline Mean \pm S.D. & $15.38 \pm 1.211$ & $15.53 \pm 1.375$ & $p=0.571$ \\
\hline
\end{tabular}

"Statistically significant $(p<0.05)$.

Table 3. Pulse rate, blood pressure, and respiratory rate in the mild preeclampsia, severe preeclampsia and control subgroup.

\begin{tabular}{|c|c|c|c|c|}
\hline & Mild PE group $(n=44)$ & Severe PE group $(n=46)$ & Control group $(n=90)$ & Significance \\
\hline \multicolumn{5}{|c|}{ Pulse rate (beats/min) } \\
\hline Min - Max & $75-90$ & $70-90$ & $70-87$ & $F=4.0377$ \\
\hline Mean \pm S.D. & $82.23 \pm 3.664^{\mathrm{a}}$ & $79.78 \pm 3.83$ & $79.69 \pm 3.139^{b}$ & $\mathrm{P}=0.015^{*}$ \\
\hline \multicolumn{5}{|l|}{ SBP (mmHg) } \\
\hline Min - Max & $140-160$ & $140-180$ & $90-140$ & $F=269.732$ \\
\hline Mean \pm S.D. & $152.27 \pm 6.853^{\mathrm{a}}$ & $168.70 \pm 10.137^{b}$ & $114.67 \pm 10.574^{\mathrm{c}}$ & $\mathrm{p}=0.000^{*}$ \\
\hline Min - Max & $80-110$ & $90-120$ & $60-90$ & $F=127.421$ \\
\hline Mean \pm S.D. & $95.45 \pm 8.579^{\mathrm{a}}$ & $108.26 \pm 7.777^{\mathrm{b}}$ & $76.22 \pm 8.059^{c}$ & $\mathrm{p}=0.000^{*}$ \\
\hline \multicolumn{5}{|c|}{ Respiratory rate (breaths/min) } \\
\hline Min - Max & $12-16$ & $12-17$ & $12-18$ & $\mathrm{~F}=2.054$ \\
\hline Mean \pm S.D. & $15.00 \pm 1.345$ & $15.74 \pm 0.964$ & $15.53 \pm 1.375$ & $\mathrm{p}=0.134$ \\
\hline
\end{tabular}

\footnotetext{
*Statistically significant $(p<0.05)$; different superscript $(\mathrm{a}, \mathrm{b}, \mathrm{c})$ indicate statistically significant difference with Tukey HSD method.
} 


\section{3) Weight, height, and BMI}

\section{a) Weight:}

There was no statistically significant difference in the weight between the two groups $(t=0.473, p=0.164)$. Using One-way independent analysis of variance (ANO$\mathrm{VA}$ ) test, there was a statistically significant difference in the weight among the three studied subgroups $(\mathrm{F}=5.538$, $p=0.005)$. Further analysis using Tukey HSD method for post-hoc revealed that weight is statistically significantly higher in mild preeclampsia group when compared with both control and severe subgroups.

\section{b) Height:}

There was no statistically significant difference in the height between the two groups $(\mathrm{t}=1.287, p=0.201)$. Using One-way independent analysis of variance (ANOVA) test, there was no statistically significant difference in the height among the three studied subgroups ( $\mathrm{F}=$ 0.841, $p=0.435$ ).

\section{c) Body mass index (BMI):}

There was no statistically significant difference in the BMI between the two groups $(\mathrm{t}=1.558, p=0.123)$. Using One way independent analysis of variance (ANOVA) test, there was no statistically significant difference in the BMI among the three studied subgroups ( $\mathrm{F}=2.933, p=$ 0.059) (Tables 4 and 5).

\subsection{Serum Level of ACE among Cases and Controls as Shown in Table 6}

There was no statistically significant difference in the serum angiotensin converting enzyme level between the two studied groups $(\mathrm{t}=1.281, p=0.204)$. Using one-way independent analysis of variance (ANOVA) test, there was no statistically significant difference in the serum angiotensin converting enzyme level among the three studied subgroups ( $F=0.825, p=0.442$ ) (Tables 6 and 7).

As regards Angiotensin converting enzyme gene polymorphism, there was no statistically significant difference between the two studied groups as well as among the studied subgroups as shown in Tables 8 and 9 .

\subsection{Risk Analysis for ACE Genotype}

As shown in Table 10 analyzing the risk of development of preeclampsia depend on presence of ACE gene polymorphism, where it showed that there was no statistically significant risk putting in consideration the two possible modes of inheritance recessive or dominant depending on the presence of the $\mathrm{D}$ allele of the gene.

Calculating the Odds ratio if we consider D allele dominant (i.e. only one $\mathrm{D}$ is enough for inheritance) it was 0.615 and the $95 \%$ confidence interval (CI) was 0.199 1.901 , therefore there was no significant difference between the three genotypes.

Calculating the Odds ratio if we consider D allele recessive (i.e. Both $\mathrm{D}$ should be present for inheritance) it was 0.824 and the $95 \%$ confidence interval (CI) was 0.347 - 1.955 , therefore there was no significant difference between the three genotypes.

Sensitivity means ability of the measured serum ACE to detect positive cases of preeclampsia. ACE (AUC = $0.594, p=0.118$ ) as a dedicated predictive factor for the occurrence of preeclampsia, there were no statistical significance as shown in (Figure 2). This cut-off value is check by the computer software (MedCalc version 10) and was chosen on the basis of the best sensitivity and specificity.

\subsection{Study of Doppler Indices of Umbilical and Uterine Arteries in Relation to the ACE Genotype}

There was no statistically significant difference between

Table 4. Weight, height, and BMI in the preeclampsia and control group.

\begin{tabular}{cccc}
\hline & $\begin{array}{c}\text { Preeclampsia } \\
\text { group }(\mathbf{n}=\mathbf{9 0})\end{array}$ & $\begin{array}{c}\text { Control group } \\
(\mathbf{n}=\mathbf{9 0})\end{array}$ & Significance \\
\hline Weight (kg) & & & \\
Min - Max & $62-136$ & $62-130$ & $\mathrm{t}=1.404$ \\
Mean \pm S.D. & $93.67 \pm 19.271$ & $88.17 \pm 17.871$ & $p=0.164$ \\
Height (cm) & & & \\
Min - Max & $150-185$ & $150-175$ & $\mathrm{t}=1.287$ \\
Mean \pm S.D. & $164.62 \pm 7.187$ & $162.82 \pm 6.031$ & $p=0.201$ \\
BMI (Kg/m $\left.\mathbf{m}^{2}\right)$ & & & \\
Min - Max & $24-61$ & $21-46$ & $\mathrm{t}=1.558$ \\
Mean \pm S.D. & $35.72 \pm 7.888$ & $33.33 \pm 6.604$ & $p=0.123$ \\
\hline
\end{tabular}

Table 5. Weight, height, and BMI in the mild preeclampsia, severe preeclampsia and control subgroup.

\begin{tabular}{|c|c|c|c|c|}
\hline & Mild PE group $(n=44)$ & Severe PE group $(n=46)$ & Control group $(n=90)$ & Significance \\
\hline \multicolumn{5}{|l|}{ Weight (kg) } \\
\hline Min - Max & $66-136$ & $62-122$ & $62-130$ & $F=5.538$ \\
\hline \multicolumn{5}{|l|}{ Height (cm) } \\
\hline Min - Max & $152-185$ & $150-184$ & $150-175$ & $F=0.841$ \\
\hline Mean \pm S.D. & $164.41 \pm 6.884$ & $164.83 \pm 7.614$ & $162.82 \pm 6.031$ & $p=0.435$ \\
\hline Min - Max & $24-50$ & $25-61$ & $21-46$ & $F=2.933$ \\
\hline Mean \pm S.D. & $37.73 \pm 6.786$ & $33.80 \pm 8.519$ & $33.33 \pm 6.604$ & $p=0.059$ \\
\hline
\end{tabular}

*Statistically significant $(p<0.05)$; different superscript $(\mathrm{a}, \mathrm{b})$ indicate statistically significant difference with Tukey HSD method. 
the three genotypes as regards umbilical and uterine artery indices except for the umbilical artery pulsitility index where a significant difference was found between the three genotypes as shown in Table 11.

\section{DISCUSSION}

Preeclampsia is characterized by hypertension, proteinurea and or oedema after the $20^{\text {th }}$ week of gestation. It is a heterogeneous disorder which complicates 5\% - 7\% of all pregnancies and remains a leading cause of maternal and fetal mortality. In Egypt, the disease complicates 6\% - $8 \%$ of all pregnancies and can reach up to $15 \%$ in referral centers like university hospitals [3].

The renin angiotensin system has been implicated to play a role in the pathophysiology of preeclampsia. Plasma and tissue angiotensin-converting enzyme (ACE) activities are believed to be under genetic control. Increased ACE activity due to the deletion polymorphism of the ACE gene is associated with a wide variety of diseases that exhibit endothelial disturbances [16].

Preeclampsia is a multisystem and multifactorial complication of pregnancy. The precise cause of preeclampsia has not been determined, but RA system may play a role. However why some women are prone to while others are protected from this disease is unknown. It has been suggested that genetic factors such as gene polymorphisms of the RA system may play an important role in the regulation of blood pressure in preeclampsia [17].

Several studies have reported that women carrying the $D$ allele of the ACEI/D polymorphism have higher ACE activity and higher measures of uterine artery resistance,

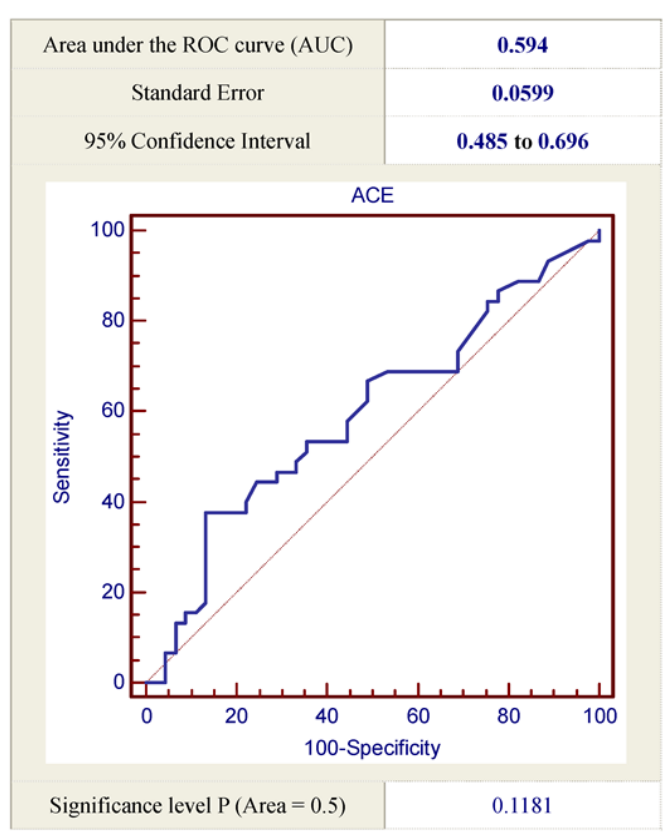

Figure 2. Sensitivity analysis for Serum ACE in detecting preeclampsia.

Table 6. Serum level of (ACE) in the preeclampsia and controls group.

\begin{tabular}{cccc}
\hline & $\begin{array}{c}\text { Preeclampsia } \\
\text { group }(\mathbf{n}=\mathbf{9 0})\end{array}$ & $\begin{array}{c}\text { Control group } \\
(\mathbf{n}=\mathbf{9 0})\end{array}$ & Significance \\
\hline ACE $(\mathbf{n g} / \mathbf{m l})$ & & & \\
Min - Max & $25-118$ & $32-130$ & $\mathrm{t}=1.281$ \\
Mean \pm S.D. & $72.20 \pm 21.960$ & $66.31 \pm 21.661$ & $p=0.204^{\mathrm{NS}}$ \\
\hline NS
\end{tabular}

Table 7. Serum level of ACE in mild preeclampsia, severe preeclampsia and controls.

\begin{tabular}{cccc}
\hline & Mild PE group $(\mathbf{n}=\mathbf{4 4 )}$ & Severe PE group $(\mathbf{n}=\mathbf{4 6})$ & Control group $(\mathbf{n}=\mathbf{9 0})$ \\
\hline ACE $(\mathbf{n g} / \mathbf{m l})$ & & & \\
Min - Max & $25-118$ & $39-113$ & $32-130$ \\
Mean \pm S.D. & $72.75 \pm 25.478$ & $71.67 \pm 18.555$ & $66.31 \pm 21.661$ \\
\hline
\end{tabular}

Table 8. Polymorphism in the preeclampsia and controls group.

\begin{tabular}{|c|c|c|c|c|c|}
\hline & \multicolumn{2}{|c|}{ Preeclampsia group $(n=90)$} & \multicolumn{2}{|c|}{ Control group $(n=90)$} & \multirow{2}{*}{ Significance } \\
\hline & $\mathrm{n}$ & $\%$ & $\mathrm{n}$ & $\%$ & \\
\hline DD (Deletion/Deletion) & 34 & 37.8 & 30 & 33.3 & \multirow{3}{*}{$\begin{array}{c}X^{2}=0.748 \\
p=0.688\end{array}$} \\
\hline DI (Deletion/Insertion) & 44 & 48.9 & 42 & 46.7 & \\
\hline II (Insertion/Insertion) & 12 & 13.3 & 18 & 20.0 & \\
\hline
\end{tabular}

$\mathrm{X}^{2}$ : Chi square test; $p: p$ value.

Table 9. Polymorphism in mild preeclampsia, severe preeclampsia and controls groups.

\begin{tabular}{|c|c|c|c|c|c|c|c|}
\hline & \multicolumn{2}{|c|}{ Mild PE group $(n=44)$} & \multicolumn{2}{|c|}{ Severe PE group $(n=46)$} & \multicolumn{2}{|c|}{ Control group $(n=90)$} & \multirow{2}{*}{ Significance } \\
\hline & $\mathrm{n}$ & $\%$ & $\mathrm{n}$ & $\%$ & $\mathrm{n}$ & $\%$ & \\
\hline DD & 20 & 45.5 & 14 & 30.4 & 30 & 33.3 & \\
\hline II & 6 & 13.6 & 6 & 13 & 18 & 20.0 & $p_{\mathrm{MC}}=0.747$ \\
\hline
\end{tabular}

MC: Monte Carlo exact test. 
Table 10. Analysis of the risk of preeclampsia according to genotype.

\begin{tabular}{|c|c|c|c|c|c|}
\hline & \multicolumn{2}{|c|}{ Preeclampsia group $(n=90)$} & \multicolumn{2}{|c|}{ Control group $(n=90)$} & \multirow{2}{*}{ Significance } \\
\hline & $\mathrm{n}$ & $\%$ & $\mathrm{n}$ & $\%$ & \\
\hline DD & 34 & 37.8 & 30 & 33.3 & \multirow{3}{*}{$\begin{array}{c}\mathrm{X}^{2}=0.748 \\
p=0.688\end{array}$} \\
\hline DI & 44 & 48.9 & 42 & 46.7 & \\
\hline II & 12 & 13.3 & 18 & 20.0 & \\
\hline If $D$ is dominant & 78 & 86.7 & 72 & 80 & $X^{2}=0.720$ \\
\hline DD \& DI & 12 & 13.3 & 18 & 20 & $p=0.396$ \\
\hline \multicolumn{6}{|c|}{ Odds ratio $=0.615,95 \%$ CI: $0.199-1.901$} \\
\hline If $D$ is recessive & 34 & 37.8 & 30 & 33.3 & $X^{2}=0.194$ \\
\hline DD & 56 & 62.2 & 60 & 66.7 & $p=0.660$ \\
\hline \multicolumn{6}{|c|}{ Odds ratio $=0.824,95 \%$ CI: $0.347-1.955$} \\
\hline
\end{tabular}

$\mathrm{X}^{2}$ : Chi square test, $p: p$ value.

Table 11. Doppler indices of umbilical and uterine arteries in relation to the genotype.

\begin{tabular}{|c|c|c|c|c|}
\hline & DD $(n=64)$ & DI $(n=86)$ & II $(n=30)$ & Significance \\
\hline $\begin{array}{c}\text { Umbilical A. SD ratio } \\
\text { Min - Max } \\
\text { Mean } \pm \text { S.D. }\end{array}$ & $\begin{array}{c}2.1-5.1 \\
2.93 \pm 0.742\end{array}$ & $\begin{array}{c}0.0-4.9 \\
2.94 \pm 0.889\end{array}$ & $\begin{array}{c}1.9-5.1 \\
2.93 \pm 0.840\end{array}$ & $\begin{array}{c}\mathrm{F}=0.001 \\
p=0.999^{\mathrm{NS}}\end{array}$ \\
\hline $\begin{array}{c}\text { Umbilical artery PI } \\
\text { Min - Max } \\
\text { Mean } \pm \text { S.D. }\end{array}$ & $\begin{array}{c}0.21-2.47 \\
1.09 \pm 0.472^{\mathrm{a}}\end{array}$ & $\begin{array}{c}0.67-4.31 \\
1.48 \pm 0.872^{\mathrm{b}}\end{array}$ & $\begin{array}{c}0.80-2.32 \\
1.12 \pm 1.124\end{array}$ & $\begin{array}{l}\mathrm{F}=3.417 \\
p=0.037^{*}\end{array}$ \\
\hline $\begin{array}{c}\text { Umbilical artery RI } \\
\text { Min - Max } \\
\text { Mean } \pm \text { S.D. }\end{array}$ & $\begin{array}{c}0.34-2.00 \\
0.69 \pm 0.275\end{array}$ & $\begin{array}{c}0.50-1.00 \\
0.68 \pm 0.128\end{array}$ & $\begin{array}{c}0.50-1.14 \\
0.66 \pm 0.154\end{array}$ & $\begin{array}{c}\mathrm{F}=0.096 \\
p=0.909^{\mathrm{NS}}\end{array}$ \\
\hline $\begin{array}{c}\text { Uterine A. S/D ratio } \\
\text { Min - Max } \\
\text { Mean } \pm \text { S.D. }\end{array}$ & $\begin{array}{c}0.00-6.30 \\
2.31 \pm 1.740\end{array}$ & $\begin{array}{c}0.00-9.2 \\
2.26 \pm 2.213\end{array}$ & $\begin{array}{c}0.00-4.60 \\
1.46 \pm 1.490\end{array}$ & $\begin{array}{l}\mathrm{F}=1.098 \\
p=0.338\end{array}$ \\
\hline $\begin{array}{c}\text { Uterine artery PI } \\
\text { Min - Max } \\
\text { Mean } \pm \text { S.D. }\end{array}$ & $\begin{array}{c}0.72-4.56 \\
2.26 \pm 1.077\end{array}$ & $\begin{array}{c}0.98-5.36 \\
2.50 \pm 1.107\end{array}$ & $\begin{array}{c}0.78-3.81 \\
2.32 \pm 0.949\end{array}$ & $\begin{array}{l}\mathrm{F}=0.510 \\
p=0.603\end{array}$ \\
\hline $\begin{array}{c}\text { Uterine artery RI } \\
\text { Min - Max } \\
\text { Mean } \pm \text { S.D. }\end{array}$ & $\begin{array}{c}0.49-1.00 \\
0.75 \pm 0.151\end{array}$ & $\begin{array}{c}0.59-2.50 \\
0.874 \pm 0.299\end{array}$ & $\begin{array}{c}0.41-1.00 \\
0.78 \pm 0.223\end{array}$ & $\begin{array}{l}\mathrm{F}=2.463 \\
p=0.091\end{array}$ \\
\hline
\end{tabular}

*Statistically significant $(\mathrm{p}<0.05)$; different superscript $(\mathrm{a}, \mathrm{b})$ indicate statistically significant difference with Tukey HSD method; ${ }^{\mathrm{NS}}$ means statistically not significant at $p<0.05$ polymorphism.

which is a marker for development of intrauterine growth retardation and preeclampsia [18,19]. These observations led to the proposal that the ACEI/D polymorphism may be a good candidate in the search for a cause of preeclampsia. We tested the hypothesis that angiotensin converting enzyme (ACE) influence the development of preeclampsia as well as Doppler changes.

Angiotensin levels are modulated by ACE, whose plasma levels have been associated with the insertion/ deletion (I/D) polymorphism in intron 16 of the ACE gene. The $\mathrm{D}$ allele, was considered the one at risk. The distribution of the ACE-I/D genotypes and allelic frequencies in our study of polymorphism was $37.8 \%$ for the DD, $48.9 \%$ for the ID, $13.3 \%$ for the II in preeclampsia group while it was $33.3 \%$ for the DD, $46.7 \%$ for the ID, and $20 \%$ for the II in the control group. According to these results, there was no significant difference between cases and control regarding the cumulative D effect .As regards the mode of inheritance of the gene, two types of analysis were done: Dominant analysis where considering that the $\mathrm{D}$ allele is dominant i.e. only one gene is enough for inheritance and recessive analysis where presence of both D alleles is needed for inheritance. By calculating Odd's ratios in both types of analysis, no significant difference was found between pre-eclamptic group and control group , therefore ACE gene polymorphism can't be suggested as a risk factor for developing preeclampsia. Regarding Doppler findings, there was no statistically significant difference between the three genotypes as regards umbilical and uterine artery indices except for the umbilical artery pulsitility index where a significant difference was found between the three genotypes. It was found that ACE gene polymorphism didn't affect serum ACE activity. Several studies were 
found supporting our results where ACE activity and ACE I/D polymorphism were not found to be associated with preeclampsia. [20] In a study done by Rasmussen et al. [21] who found that serum ACE activities were lower in patients with preeclampsia than women with normal pregnancy, and proposed that this phenomenon reflects a decreased placental synthesis of ACE in preeclampsia. In a relative small study in Korean women, the I allele of the ACE gene was associated with preeclampsia. In each ACE genotype, there was no significant association between the genotypes and the onset of proteinuria and hypertension. No association of pregnancy outcome with ACE genotype [22].

Another study in black South African population where no significant differences in the distribution of any of these polymorphisms were found between patients with preeclampsia or eclampsia and the normal control subjects. Patients with gestational hypertension were less frequently homozygous for the ACE insertion polymorphism compared with controls. They concluded that the commonly occurring rennin angiotensin system polymorphisms are not predictive of preeclampsia or eclampsia in the Black South African population [23].

Another study was conducted on German women to evaluate the influence of ACE gene polymorphism on individual predisposition to preeclampsia where results did not indicate an association of the gene with preeclampsia [24].

Another genetic association study was conducted at the obstetrics department of the Charite university hospital, Berlin, Germany. A total of 1068 Caucasian women were consecutively included and genotyped the angiotensin-converting enzyme (ACE) insertion/deletion polymorphism. They concluded that in a large Caucasian population a common maternal polymorphism of the angiotensinogen gene is related to a blood pressure increase during pregnancy. The angiotensinogen polymorphism might contribute to the multifactorial pathogenesis of gestational hypertension and preeclampsia. Maternal polymorphisms do not influence fetal growth and birth weight [25]. These results were different from ours since the study was conducted on a large population sample. Another study was done on Japanese patients to elucidate genetic risk factors for preeclampsia and gene-environment interactions in the manifestation of preeclampsia Patients with preeclampsia and normal pregnancy controls were examined for the presence of variants of candidate genes such as angiotensin converting enzyme (ACE) gene. The results suggest that this variant gene may play a role in the manifestation of hypertension together with other independently and/or synergistically acting factors, particularly in primiparous pregnancy [26].

In the institute of Experimental Medical Research, Istanbul University in Turkey, some investigaters examined the insertion/deletion genotype distribution and the activity of ACE in preeclamptic pregnants. The presence of D allele was found to be associated with preeclampsia. The influence of allelic distribution on the enzyme activity was observed in the preeclamptics bearing II genotype, who exhibited significantly lower activity of ACE than that of the patients with the other genotypes. Investigators found an association between the genotype II and low ACE activity in preeclamptic women and an association between $\mathrm{D}$ allele frequency and preeclampsia. Pregnancy alone did not have an effect on the ACE activity [27].

Another study was carried out at the University Medical School of Lublin in Poland on patients with singleton pregnancy complicated by preeclampsia between 33 and 40 weeks of gestation. The serum ACE activity was estimated using spectrophotometry. It was noted that there were no statistically significant differences in patients' profiles between groups in gravidity, parity, maternal age, gestational age and the mode of delivery. Overall, the study revealed elevated maternal and umbilical serum ACE activity in pregnancies complicated by preeclampsia. Hence, it indicates a significant role of ACE in pregnancy complicated by preeclampsia [28].

These results were different from ours since they used spectrophotometry instead of more specific technique like ELISA, also this study did not relate enzyme activity to presence or absence of gene polymorphism but researchers discussed only the role of the enzyme with the development of preeclampsia.

The preeclampsia subgroups ; there was no statistically significant difference between the three genotypes as regards umbilical artery Doppler assessment but for the uterine artery Doppler assessment, there was a significant difference between the three genotypes. Studying the uteroplacental and umbilical blood flows shows that there was no association between ACE gene polymorphism and defective blood flow at both levels. This matches with results proposed by Guo et al. [29] who found that there was no significant difference in the genotypes frequencies of the M235T allele between preeclampsia/eclampsia cases and controls in Australian and Chinese population [30,31].

Differences in the results between available literature depend on the study population and geographic location also the technique used. Despite the growing evidence of the genetic background of preeclampsia in literature, there are still gaps in our knowledge. The size of the estimated risks varies between individual studies due to heterogenecity in study design. More large scale studies are required to better assess the actual relation of ACE gene polymorphism and preeclampsia since this will inform physicians and help determine optimum management and prevention strategies. Genetic studies in preec- 
lampsia continue to be somewhat small in size [32,33] and are usually underpowered to detect realistic genotypic relative risks (ORs between 1.15 and 1.4).

Despite these obstacles, the investment in adequate resources to study the genetics of preeclampsia is an important priority. Observational studies and the randomized trials of interventions that have to be followed have been unsuccessful thus far in identifying causal pathways in preeclampsia amenable to preventive therapies, a clear example of which are the recently failed clinical trials using either antioxidant vitamins or calcium supplements [34].

A genetic approach that is less prone to confounding and reverse causation than nongenetic observational studies, may be more likely to identify causal pathways and may help to prioritise therapeutic targets that require evaluation in large and expensive randomized clinical trials [34]. The challenge is in how to make better use of the genetic approach in complex diseases such as preeclampsia, in particular to overcome random errors in risk estimates from small studies as well as publication bias and also to overcome the high cost of the genetic testing versus the regular serum level estimation.

\section{CONCLUSIONS}

In the present study, we reached the following conclusions:

1) No existence of a relation between preeclampsia and ACE gene polymorphism considering different modes of inheritance whether is dominance or recessiveness.

2) No effect of ACE gene polymorphism on ACE serum level.

3) The only positive finding we had was the relation between ACE gene polymorphism and the uterine artery Doppler changes which made us suggest that ACE gene may have a role in the histopathological changes taking place in these vessels and therefore affecting maternal and fetal prognosis.

International collaborations, particularly among those countries with a high incidence of preeclampsia, may help to include participants with different cultural and genetic backgrounds, which can provide further insight into the aetiology of the disease both genetic and/or environmental.

\section{REFERENCES}

[1] López-Jaramillo, P., Pradilla, L.P. and Castillo, V.R. (1988) Geographic variation in the incidence of hypertension in pregnancy. World Health Organization International Collaborative Study of Hypertensive Disorders of Pregnancy. American Journal of Obstetrics \& Gynecology, 158, 8083. http://dx.doi.org/10.1016/0002-9378(88)90782-X

[2] Lopez-Jaramillo, P., Casas, J.P. and Serrano, N. (2001)
Preeclampsia: From epidemiological observations to molecular mechanisms. Brazilian Journal of Medical and Biological Research, 34, 1227-1235. http://dx.doi.org/10.1590/S0100-879X2001001000001

[3] Shaaban, M.M. (2006) Hypertensive disorders in pregnancy. Obstetrics Theory and Practice, 1, 173.

[4] The Eclampsia Trial Collaborative Group (1995) Which anticonvulsant for women with eclampsia? Evidence from the collaborative eclampsia trial. Lancet, 345, 1455-1463.

[5] Skeggs, L.T., Kahn, J.R. and Shumway, N.P. (1956) Preparation and function of the hypertensin converting enzyme. The Journal of Experimental Medicine, 103, 295299. http://dx.doi.org/10.1084/jem.103.3.295

[6] Broughton Pipkin, F. (1999) What is the place of genetics in the pathogenesis of pre-eclampsia? Biology of the Neonate, 76, 325-330.

http://dx.doi.org/10.1159/000014175

[7] Shah, D.M. (2006) The role of RAS in the pathogenesis of preeclampsia. Current Hypertension Reports, 8, 144152.

[8] Mello, G., Parretti, E., Gensini, F., Sticchi, E., Mecacci, F., et al. (2003) Maternal-fetal flow, negative events, and preeclampsia: Role of ACE I/D polymorphism. Hypertension, 41, 932-937. http://dx.doi.org/10.1161/01.HYP.0000063146.40351.AD

[9] Kammerer, C.M., Gouin, N., Samollow, P.B., VandeBerg, J.F., Hixson, J.E., et al. (2004) Two quantitative trait loci affect ACE activities in Mexican-Americans. Hypertension, 43, 466-470.

[10] Keavney, B., McKenzie, C., Parish, S., Palmer, A., Clark, S., et al. (2000) Large-scale test of hypothesised associations between the angiotensin-converting-enzyme insertion/deletion polymorphism and myocardial infarction in about 5,000 cases and 6,000 controls. Lancet, 355, 434442. http://dx.doi.org/10.1016/S0140-6736(00)82009-7

[11] Sayed-Tabatabaei, F.A., Houwing-Duistermaat, J.J., Van Duijn, C.M. and Witteman, J.C. (2003) Angiotensin-converting enzyme gene polymorphism and carotid artery wall thickness: A meta-analysis. Stroke, 34, 1634-1639.

[12] Bonnici, F., Keavney, B., Collins, R. and Danesh, J. (2002) Angiotensin converting enzyme insertion or deletion polymorphism and coronary restenosis: Meta-analysis of 16 studies. British Medical Journal, 325, 517-520. http://dx.doi.org/10.1136/bmj.325.7363.517

[13] National Institute of Child Health and Development (2001) Conference summary: Amniotic fluid biology-basic and clinical aspects. The Journal of Maternal-Fetal Medicine, 10, 2-19. http://dx.doi.org/10.1080/jmf.10.1.2.19

[14] Altman, D.J. and Chitty, L.S. (1993) Design and analysis of studies to derive fetal charts of fetal size. Ultrasound in Obstetrics \& Gynecology, 3, 378-384.

[15] Chudleigh, T. and Thilaganathan, B. (2004) Routine second trimester screening-assessing of gestational age. In: Chudleigh, T. and Thilaganathan, B., Eds., Patricia Obstetric Ultra-Sound: How Why, and When? 3rd Edition, Elsevier Churchil Living Stone, 95-112.

[16] Figen, G., Elif, B., Hulya, Y., Turgay, S. and Ahmet, D. (2004) The association between preeclampsia and angi- 
otensin-converting enzyme insertion/deletion polymorphism. Clinica Chimica Acta, 341, 127-131.

[17] Roberts, J.M. and Lain, K.Y. (2002) Recent insights into the pathogenesis of pre-eclampsia. Placenta, 23, 359-372. http://dx.doi.org/10.1053/plac.2002.0819

[18] Shim, S.S., Shim, J.Y., Lim, J.H., Park, J.S., Jun, J.K., Bai, K.B., Yoon, B.H. and Syn, H.C. (2003) Molecular biological approach to find out the etiology of hypertensive disorder in pregnancy: Analysis of the polymorphism in the promoter of human angiotensinogen gene in Korean population. Korean Journal of Obstetrics \& Gynecology, 46, 1486-1492.

[19] Morise, T., Takeuchi, Y. and Takeda, R. (1995) Rapid detection and prevalence of the variants of the angiotensinogen gene in patients with essential hypertension. Journal of Internal Medicine, 237, 175-180. http://dx.doi.org/10.1111/j.1365-2796.1995.tb01158.x

[20] Langer, B., Grima, M., Coquard, C., Bader, A.M., Schlaeder, G. and Imbs, J.L. (1998) Plasma active renin, angiotensin I, and angiotensin II during pregnancy and in preeclampsia. Obstetrics \& Gynecology, 91, 196-202. http://dx.doi.org/10.1016/S0029-7844(97)00660-1

[21] Rasmussen, A.B., Pedersen, E.B., Romer, F.K., Johannesen, P., Kristensen, S., Lauritsen, J.G. and Wohlert, M. (1983) The influence of normotensive pregnancy and pre-eclampsia on angiotensin-converting enzyme. Acta Obstetricia et Gynecologica Scandinavica, 62, 341-344. http://dx.doi.org/10.3109/00016348309156235

[22] Roh, C.R., Kim, D.K., Yoon, B.K., Yang, S.H., Chung, J.H., Bae, D.S. and Lee, J.H. (1997) A common genetic variant of the angiotensin converting enzyme (ACE) gene and pregnancy induced hypertensive disorders. Korean Journal of Obstetrics \& Gynecology, 40, 1189-1199.

[23] Roberts, C.B., Rom, L., Moodley, J. and Pegoraro, R.J. (2007) Hypertension-related gene polymorphisms in preeclampsia, eclampsia and gestational hypertension in Black South African women. European Journal of Obstetrics, Gynecology, and Reproductive Biology, 131, 115-126.

[24] Knyrim, E., Muetze, S., Eggermann, T., Rudnik-Schoeneborn, S., Lindt, R., Ortlepp, J.R., Rath, W. and Zerres K. (2008) Genetic analysis of the Angiotensinogen gene in pre-eclampsi. Gynecologic and Obstetric Investigation, 66, 203-208. http://dx.doi.org/10.1159/000146084

[25] Choi, H., Kang, J.Y., Yoon, H.S., et al. (2004) Association of angiotensin-converting enzyme and angiotensinogen gene polymorphisms with preeclampsia. Journal of Hypertension, 22, 945-948.
[26] Kobashi, G. (2003) Gene polymorphisms and preeclampsia in Japanese; Analysis for gene-environment interaction. Acta Obstetrica et Gynaecologica Japonica, 55, 817829 .

[27] Laskowska, M., Laskowska, K. and Oleszczuk, J. (2002) Angiotensin-converting enzyme activity in pre-eclampsia. International Journal of Gynecology and Obstetrics, 77, 33-34. http://dx.doi.org/10.1016/S0020-7292(01)00580-X

[28] Jacob, H.J., Lindpaintner, K., Lincoln, S.E., Kusumi, K., Bunker, R.K., Mao, Y.P., Ganten, D., Dzau, V.J. and Lander, E.S. (1991) Genetic mapping of a gene causing hypertension in the stroke-prone spontaneously hypertensive rat. Cell, 67, 213-224. http://dx.doi.org/10.1016/0092-8674(91)90584-L

[29] Jeunemaitre, X., Soubrier, F., Kotelevtsev, Y.V., Lifton, R.P., Williams, C.S., Charru, A., Hunt, S.C., Hopkins, P.N., Williams, R.R., Lalouel, J.M. and Corvol, P. (1992) Molecular basis of human hypertension: Role of angiotensinogen. Cell, 71, 169-180. http://dx.doi.org/10.1016/0092-8674(92)90275-H

[30] August, P. and Sealey, J.E. (1990) The renin-angiotensin system in normal and hypertensive pregnancy and in ovarian function. Hypertension; Pathophysiology, Diagnosis, and Management, 1761-1778.

[31] Yu, C.K., Casas, J.P., Savvidou, M.D., Sahemey, M.K., Nicolaides, K.H., et al. (2006) Endothelial nitric oxide synthase gene polymorphism (Glu298Asp) and development of pre-eclampsia: A case-control study and a metaanalysis. BMC Pregnancy Childbirth, 6, 7. http://dx.doi.org/10.1186/1471-2393-6-7

[32] Lin, J. and August, P. (2005) Genetic thrombophilias and preeclampsia: A meta-analysis. Obstetrics \& Gynecology, 105, 182-192.

http://dx.doi.org/10.1097/01.AOG.0000146250.85561.e9

[33] Rumbold, A.R., Crowther, C.A., Haslam, R.R., Dekker, G.A. and Robinson, J.S., ACTS Study Group (2006) Vitamins $\mathrm{C}$ and $\mathrm{E}$ and the risks of preeclampsia and perinatal complications. New England Journal of Medicine, 354, 1796-1806. http://dx.doi.org/10.1056/NEJMoa054186

[34] Hingorani, A.D., Shah, T. and Casas, J.P. (2006) Linking observational and genetic approaches to determine the role of C-reactive protein in heart disease risk. European Heart Journal, 27, 1261-1263. http://dx.doi.org/10.1093/eurheartj/ehi852

\author{
ABBREVIATIONS \\ ACE: Angiotensin Converting Enzyme \\ I/D: Insertion/Deletion \\ PE: Preeclampsia
}

